\title{
Neogothic Space Interpretation
}

\author{
${ }^{\mathbf{1}}$ Lily R. Mukhametzyanova, ${ }^{2}$ Michail K. Yao, ${ }^{3}$ Juliana G. Emanova, ${ }^{4}$ Kseniya G. Pozdnyakova \\ 1, 2, 3 Kazan Federal University Institute of Philology and Intercultural Communication named after L. \\ Tolstoy, ${ }^{4}$ Saint-Petersburg State University \\ Email:aklilya@bk.ru
}

\section{Received: 15th December 2017, Accepted: 20th December 2017, Published: 31st December 2017}

\begin{abstract}
The article considers the specific features of Gothic motifs interpretation in different countries and in different historical periods: Gothic motifs in baroque Italy and the Czech Republic, Germany and England of the 19th century and in more thoroughly in Russia. Medieval motifs coexist harmoniously with the elements of different styles in small forms. The symbolic fullness of the Gothic material environment proved to be spiritually attractive to the rationalistic era of the Industrial Revolution. NeoGothic has expressed the desire of house and interior customers to oppose an individual to a public. In different countries, Neo-Gothic had a specific semantic content from a romantic fairy tale to the manifesto dedicated to the triumph of technological progress. A wide interest for Gothic in Russia appears under the influence of Romantic literature. Russia and other countries experienced the contradiction between building exterior and interior. The use of the term "pseudo-Gothic" in Russia reveals a negative connotation in the evaluation of Neo-Gothic as an eclectic style. The review of NeoGothic buildings in Russia made it possible to single out three periods of neo-Gothicism with specific stylistic solutions. Neo-Gothic interpretation of the object-spatial environment sought to combine gothic aesthetics with the comfort of modern times. The interior and the furniture of the Neo-Gothic period are subject to a common ideological and conceptual design. The article reveals the value and aesthetic reasons for the turning to neo-Gothic.
\end{abstract}

Keywords. Neo-Gothic, Pseudo-Gothic, Gothic, Style Interpretation, Gothic Architecture, Gothic Interior, Interior Reconstruction, Gothic Furniture.

\section{Introduction}

Traditionally it is believed that the forgotten Gothic was reopened by romantics in the late 18th and early 19th centuries. Let's recall that the actual Gothic style, the style of a medieval city arose and existed in Western Europe from the 11th to the 15th century. Each of the subsequent large styles replaces the previous style, radically transforming or even denying it. But the development of the chamber architecture of living quarters and arts and crafts shows that there is no mutual denial between these styles in small forms. Even in the 18th century, the European household items made in the province, show the elements of design and decor, taken from the Gothic style, which are combined with details and ornamental motifs, both of Renaissance and Baroque. Great styles combine love for natural materials and decorative expressiveness. The decorative elements in them are comprehended aesthetically and combined into a holistic solidity of forms with its decorative juiciness and decorating elements. They are characterized by unity of an expressive form, the conformity to its purpose, an aesthetic comprehension of material plastics and an expressive, memorable decor.

\section{Methods}

The analysis of the issue history, the aesthetic principles of Neo-Gothic, the stylistic review of Neo-Gothic structures abroad and in Russia, made it possible to determine the specific nature of this trend in Russia. Cultural, historical, stylistic, comparative analysis of the era documents, phenomena and facts, the architectural structures and furniture items suggests the change in the negative attitude towards this trend in art history.

\section{Results}

The interest in Gothic never went away [1-2]. The Gothic buildings were erected in Italy of the 17 th century, during the Baroque era, by Karl Rinaldi and Guarino Guarini, as well as by Jan Blazhem in the Czech Republic. Even the founder of British Classicism, Christopher Wren built an externally purely Gothic tower of Tom in Oxford in the early 1680s. The neo-Gothic castle of the Duke of Argyll on the Scottish lake of Loch Fain was built in the 1740-ies. In the second half of the XIX-th century Gothic dreams touched Germany, a striking example can be the castles of Hohenschwangau and Neuschwanstein in Bavaria, erected on the site of the collapsed fortresses. Gothic has spread even in those countries where it could not be erected in its historical time. The interpretation of Gothic motifs in the wooden architecture of Canada, called "Carpenter Gothic" or "Rural Gothic" can be an example. Gothic entered confidently in the twentieth century, and the work "American Gothic", created in 1930 by Grant DeVolson Wood [3] clearly demonstrates this. It is noteworthy that the house depicted on the picture is a real object and is listed in the National Register of Historic Places (1974) as Dibble House.

If neo-Gothic became a surreal attribute of national self-consciousness for America, then it acquired a completely different sounding in England. The neogothic of London Parliament building (Westminster Palace) creator, Augustus Welby Northmore Pugin (together with Sir Charles Barry) is an ambitious 
antithesis to the English "vanity fair" of the mid-19th century. According to the architects' plan, the newly resurrected Gothic was called upon to create a new majestic style, a new ideological content that would bring back lost spiritual values. The ruined colossal ensemble Fonthill Abbey, also known as Beckford's Folly (built in 1795-1813) by the architect James Wyeth was filled with the same spirit. This is a country house with a hundred-meter high Gothic tower in the village of Fontill-Gifford in Wiltshire was built for the author of William Beckford's Gothic novels. Gothic attracted by its unusualness, therefore, Neo-Gothic was chosen when an architectural solution was needed to develop the railway - a new vehicle and the product of the Industrial Revolution. The merger of the old and the new was embodied in the architecture of the St Pancras railway station, built by Sir George Gilbert Scott. (It is not by chance that the cover of the Bauhaus' Manifesto - the engraving for Lionel Faininger - depicts a stylized Gothic temple - a symbol of the unification of high art and industry). In England the Neo-Gothic had a wide practical and theoretical development. The fascination of preRaphaelite artists by medieval England, the successful aesthetic studies by William Morris encircled Gothic with the halo of spirituality and aesthetic perfection, in which benefit and beauty were combined. Each ambitious architect of the "Gothic Revival" had to read the "Stones of Venice" (1874) by the theoretician of art John Ruskin, get acquainted with the "History of the Gothic Revival" (1864) by Charles Lock Eastlake [4]. One of the bright guides of Neo-Gothic and the ideas of aesthetics was Edward William Godwin, who "opened his own architectural firm in 1854, which was engaged in school and house projects using the "Gothic style" [4; 155]. The town hall in Northampton was a characteristic building by E.W. Godwin. Its interior is noteworthy. The space of a large hall was decided in the form of a central nave of Gothic cathedral with round windows - roses. The very interpretation of the hall volume is unexpectedly close to the treatment of the Imperial Main Stables Manege (1848-1855) in Peterhof, built by the Russian architect Nikolai L. Benois. NeoGothic will get its further, triumphant development at the Glasgow School, in the works by Charles Rennie Mackintosh at Hill House in Helensburg (1903) and in the interiors of tea rooms [5].

In Russia, Neo-Gothic appears in the 18th century the century of architecture rapid development that lasted for one century from an early Baroque to late classicism - empire. Yuri M. Felten - the representative of an early stage of classicism can be considered as the first architect of Neo-Gothic. His ensemble of the Chesme Palace (1774-1777) includes an exquisite church of John the Baptist, performed in the best traditions of late Gothic. The unfinished large-scale palace and park ensemble in Tsaritsyno (founded in 1776) by Vasily I. Bazhenov is full of Gothic decor. The creator of the amplest ensembles Carl Rossi was fascinated by Gothic. In 1808 he made the architectural and began the construction of the church of St. Catherine in the Moscow Kremlin (1817 is the end of construction, it was destroyed in 1929).

The Gothic of modern times, which is called "neoGothic" in literature, entered the history of culture as the part of Historism period [6]. In Russia, the term "pseudo-Gothic" was more widely used. You can feel a negative attitude in the prefix "pseudo", which in our opinion is unfair in relation to the Russian buildings of this imaginative trend. Chronologically, Russian neo-Gothic can be divided into three periods. The first one is represented by early neoGothic buildings of the late XVIII - early XIX centuries. The second stage takes place during 1820 - 1850 and coincides with the period of Nicholas I reign. The interest in gothic at that time, along with already mentioned factors, was determined by the sympathies of the imperial court. It is known that in 1816 during the trip to Europe Grand Duke Nikolai Pavlovich (future Nicholas I) visited Scotland, where he met Walter Scott. This meeting greatly influenced the development of his taste. The interest of Nicholas I was shared by his wife Alexandra Fedorovna, the daughter of the Prussian King Frederick William III. The fascination of two crowned spouses with the ideas of romanticism became the guarantee of the fact that Gothic style became a fashion that embraced quite wide layers of society. The works by I.V. Goethe, F. Schiller, E. Hoffmann, later by P. Merimee and V. Hugo were also read in Russia and at the beginning of the 20th century the novels by J.-C. Huysmans were read. Russia had its own Walter Scott - Alexander Bestuzhev-Marlinsky (1797 - 1837). The world of images of this literature was so unlike either reality or the past of Russia. The idea of these images materializing was interesting not so much for architects, but for their customers - the enlightened representatives of the court and aristocracy. Gothic forms are spread in suburban, manor architecture, where the images of architecture are inseparably connected with the surrounding landscape. This is the main difference between New Gothic and the Gothic of the middle Ages, which was connected with a city - the space of people and was a bridge between them and the heavens.

The second period of Neo-Gothic is characterized by the attention to external elements, which sometimes come into conflict with the design features of the building or the objects of decorative and applied art. This time is represented by most of 
neo-Gothic buildings in Russia. The third period of neo Gothic is represented at the turn of the XIX - XX centuries. It is close to the second one, but it is more organic and artistic. The main thing here is not so much the accuracy of historical details, but their plasticity and the compliance with an integral image - this is the beginning and an integral part of Modern [7].

Many neo-Gothic buildings, churches, public buildings and estates were erected in Russian provinces. The Cathedral of the Assumption of the Blessed Virgin Mary was built in Irkutsk (1884) in the neo-Gothic style according to Jan Tamulevich's project, Sevastyanov's house in Yekaterinburg (1863-1866, the architect A.I. Paduchev) and the Lutheran Church of St. Catherine in Kazan (18621865, the architect L.K. Khrschonovich). One of the brightest buildings is the Catholic Church of the Sacred Heart of Jesus in Samara, the construction took place from 1902 to 1906 according to the project of Thomas Bogdanovich-Dvorzhetsky (1859 - 1920). Several ensembles of the neo-Gothic style were built in the Crimea - "Romantic Alexandria" (1830-ies, designed by Philip Elson) and "Swallow's Nest", designed by Leonid Sherwood (1911 - 1912).

During the study of neo-Gothic style, both in Russia and in other countries, there is a contradiction between the exterior and the interior of the buildings. Gothic romanticism excited with external elements above all. The harsh conditions of life in the middle Ages could not produce the objects that would have found application in the elegant XVIII-th and the pragmatic XIX-th centuries. Of course, the interior of neo-Gothic is a comfortable interior of the new time. Here the style does not create an essential image, but rather an entourage with finials, roses and pointed arches, Gables, pinacles and vials. From the stone details of architecture, they turned here into decor, materializing the fantasies of romantics. Later, neo-Gothic was regarded as an insignificant eclectic. This explains a limited number of authentic neo-Gothic interiors that have reached us. The first piece of Gothic style furniture in Russia was wooden screens consisting of numerous sections that entered the interiors of Tsarskoe Selo and Peterhof since the 1770-ies [8]. At the same time, the first furniture sets and individual objects were created in neo-Gothic style. At the initial stage, the neo-Gothic masters preferred solid mahogany, refusing to veneer, and the samples of it were the items of English furniture makers such as Thomas Chippendale, George Hepplewhite and Thomas Sheraton [9-11]. A characteristic feature of the first samples of Russian furniture is the use of crossed pointed arch motives on the backs of chairs and armchairs. We have a more complete idea of Neo-Gothic interior of the second period - 1820-ies - 1850-ies. Here mahogany,
Karelian birch and poplar, the main materials of the Empire, are replaced by native species: oak, ash, alder, wavy birch and walnut. In the workshop of Gambs and his sons, the Russian neo-Gothic has acquired an interesting feature, which can be called a national one, it consists of a contrast combination of light backgrounds of ash wood or wavy birch with dark decorative carved elements of toned walnut or oak.

\section{Discussion}

Among all the objects of Russian neo-Gothic the Cottage Palace is the best of preserved ones. It was built in Peterhof in the Alexandria Park under the project by Adam Menelas. The cottage was thought as a country house for the private life of the imperial family from the very beginning. The Empress Alexandra Feodorovna told the guest the following: "My life in the palace of Peterhof is unbearable. In order to rest from its heavy gilding, I asked the Emperor for this modest abode. I've never been as happy as here." The cottage was decided to build on the site of Alexander Menshikov's palace "Monkuraz" ruins [12; 271]. The work on the project was started in 1826, and the main works were completed by 1829 . The architect understood the essence of the order exactly and embodied new noteworthy forms in it. The main feature of the entire building is the intimacy of the scale, the comfort of planning and the rejection of the centrally symmetric principle, so characteristic of Russian architecture. The cottage was designed during the period when the Empire ensembles of Mikhailovsky Palace and the General Staff of Carl Rossi were created with peculiar and spectacular enfilades, piercing the whole building. The first thing that Menelas refuses in this construction is the enfilade, which subordinates all volumes and dictates the position of each detail, sometimes regardless of its functional significance. The architect takes into account the needs of private life. All volumes enjoy much greater autonomy than in previous architectural solutions. A functional role is taken into account in the features of each of them, therefore the total volume is not a single whole collected at the will of the architect, but the sum of the individual rooms, each of which fulfills its function. Such a confederal principle of space organizing will become typical later. In general, the artistic image of a building consists of a set of protruding and recessed volumes. The Cottage visitor feels a pleasant harmony and comfortable scale of these volumes. The balcony and the arcade above the entrance decorated with Gothic motifs bring an elegant element to the ensemble. And the arcade is an openwork design made of metal. The possibilities of the material make it possible to create a light lace composition, consonant with the ribbed vaults of late Gothic. The cottage original interiors can be judged only by the watercolors of Edward 
Hau and the portrait of Alexandra Feodorovna in the interior of the Gothic drawing room by Alexander Bryullov (Fig. 1). All the original furniture in the Neo-Gothic style was made according to the projects of Menelas in Henry Gamb workshops from 1829 to 1834. The atmosphere of the Gothic Cottage can be felt on the portrait of Alexandra Feodorovna. Here, a chair decorated with Gothic motifs, a door, a window frame and a jardinier screen with multicolored "gothic" stained-glass inserts are combined in a thoughtful ensemble.

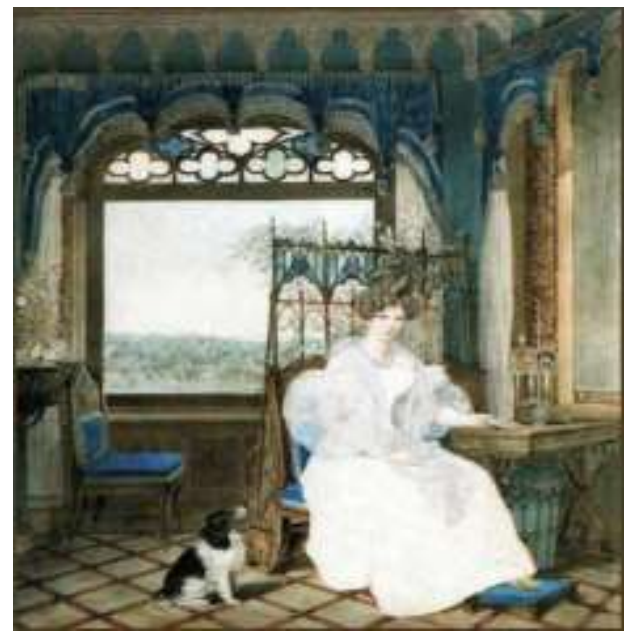

Fig.1. Painter Alexander Bryullov. Empress Alexandra Fedorovna. State Art and Architectural Palace and Park Museum-Reserve "Peterhof", 1830.

New features are acquired by neo-Gothic during the third period of its development. At this time the following authors worked in Neo-Gothic style: Fedor O. Shekhtel, Alexander V. Kuznetsov, Leonid V. Sherwood, Pyotr S. Boytsov, Alexander F. Krasovsky, Roman I. Klein, Thomas O. Bogdanovich-Dvorzhetsky and many others. Since the 1880-ies, the neo-Gothic ensembles of Russia demonstrate the impact of Modern. Modern thinks of itself as a secession, i.e. the movement that opposes the carriers of this trend to the common practicality of the era, and Gothic was an expressive form of this Secession. Comfort is valued as in the external appearance, so as in the interior, in the neo-Gothic buildings of the third period, the facade is projected proceeding from the inner space logic - "inside out". In practice, this manifested itself in a free asymmetric interior layout, their freeing from officialism.

\section{Summary}

A large number of neo-Gothic monuments were destroyed in the Second World War and their restoration was waiting for its hour during a long time. Until recently the restoration work has been represented by the objects of Great Styles. NeoGothic as an eclectic style, was perceived as an insignificant artistic phenomenon for a long time, and therefore was not interesting for experts. Only recently it has occupied a worthy place in the matter of cultural object revival and preservation.

\section{Acknowledgements}

The work is performed according to the Russian Government Program of Competitive Growth of Kazan Federal University.

\section{References}

1. Pile F. John. A History of Interior Design Laurence. - London: King Publishing, 2005.- 464 p.

2. Pile F. J, Gura Judith. History of Interior Design. - New York: John Wiley \& Sons, 2013. - 496 p.

3. Art: The Definitive Visual Guide / вy Andrew Graham-Dixon. - London: Dorling Kindersley, 2008. $-612 \mathrm{p}$.

4. Lambourne L. The Aesthetic Movement. London: Phaidon Press, 2011.- 240p.

5. The Art of Modern .- M.: Eksmo, 2012.- 240 p.

6. The results of all ages. The era of historicism in Russia (1820 - 1890): the catalog of the exhibition from the collection of the State Hermitage. - SPb.: Slavia, 2014. - $271 \mathrm{p}$.

7. Yamshanov I.V. Neo-Gothic architecture in Russian Empire during the Modern Age // Architecton: News of Universities. - No. 36.- 2011.http://archvuz.ru/2011_4/12

8. Bartenev I.A., Batazhkova V.N. Russian interior of XVIII -XX centuries. - L.: Fine Arts, 1968. - 360 p.: ill.

9. Morley J. The History of Furniture: Twenty-Five Centuries of Style and Design in the Western Tradition. - London: Thames\& Hudson LTD, 1999.$352 \mathrm{p}$.

10. Bulgakova A.V., Yao M.K. Principles of the neo-Gothic interior organization on the example of the main house of Taraskov's estate // Bulletin of the International Institute of Antiques "World of Arts" .2017.- No. 1.- pp. 30 - 57.

11. Miller. J. Furniture: World Styles from Classical to Contemporary. - London: DK, 2005. - 560 p.

12. Custine de Astolph. Russia in 1839. - Moscow: The publishing house named after Sabashnikovs, 1996. - 528 p. 